\title{
Oxidative stability of breast meat from broilers fed diets supplemented with synbiotic and organic acids
}

\author{
Untea Arabela Elena*1; Panaite Tatiana Dumitra1 \\ ${ }^{*}$ Corresponding author: arabela.untea@ibna.ro
}

${ }^{1}$ National Institute of Research-Development for Biology and Animal Nutrition - IBNA Balotesti, Calea Bucuresti, No. 1, Ilfov, Romania

\section{ABSTRACT}

The purpose of this study was to investigate the effect of synbiotic and organic acids on oxidative stability of breast broiler meat. The experiment consists on 120, 2 days old Ross 308 chicks, housed in metabolic cages (6 chicks/cage). A $2 \times 2$ factorial arrangement was considered with 4 treatments and 5 replicates ( 30 animals per group). Two different levels of synbiotic ( 0 and $10 \mathrm{~g} / \mathrm{kg}$ ) and two different levels of organic acids (0 and $1.5 \mathrm{~g} / \mathrm{kg})$ were added to the standard diets in order to constitute the four experimental diets. For further analysis, breast meat from 6 animals per group were collected in $42^{\text {nd }}$ experimental day. No significant differences were noticed for any oxidative parameter measured in breast samples except TBARS (significant decreased values for $\mathrm{OA}$ supplemented groups), at the end of experiment. After 4 days of refrigeration $\left(4^{\circ} \mathrm{C}\right)$, the secondary oxidative products (panisidine, TBARS) were significant smaller for E groups, compared to C. After 7 days of refrigeration $\left(4^{\circ} \mathrm{C}\right)$, the OA groups had significant smaller values for primary (CD) and secondary oxidation products. Synbiotic and organic acids supplements presented positive effect on meat quality by increasing oxidative stability of breast meat during storage.

Keywords: meat, oxidative status, organic acid, synbiotic

\section{INTRODUCTION}

Terms such quality of meat are related to physical, chemical and microbiological properties of product (Stamilla et al., 2020). A direct relation can be noticed between broilers meat shelf life, meat quality and animal feeding. The nutritional value of meat products, flavour, colour and texture are parameters influenced by lipid peroxidation (Abd El-Samee et al., 2019). 
Nutritional strategies for delaying of oxidation process of meat can reduce economic losses, food waste and increase consumer acceptance (Viana et al., 2017). Dietary supplements used for improving the quality of meat are synthetic or natural antioxidants, pro or prebiotics, organic acids (Galli et al., 2020) etc and they action through diffrent pathways like scavenging the free radicals or improving the intestinal health.

Synbiotics are mixture of probiotics and prebiotics and today are considered functional feed supplements in animal nutrition (Dev et al., 2020). The effect of combined probiotics and prebiotics is considered to be superior to the individual use and results in better animal performance (Hassanpour et al., 2013). The synbiotic use as supplements in broilers diet led to a hypocholesterolemic effect (Liong et al., 2007). Dev et al., (2020) showed that a combination of Lactobacillus acidophilus and mannan-oligosaccharides improves growth performance and body antioxidant defence system of broilers. In several studies on synbiotic supplements in broilers diet, the TBARS value (thiobarbituric acid reactive substances) was used as marker of lipid oxidation of meat, and the results showed significant improvement of meat quality from this point of view (Ghasemi et al., 2016).

Organic acids are short chain acids which present antimicrobial activity (Shahidi et al., 2014). The use of organic acids in broilers nutrition showed improvement of body weight and feed conversion ratio (Khan et al., 2016), significant effects on intestinal health (Rodríguez-Lecompte et al. 2012), improved apparent ileal digestibility of dry matter and crude protein (Garciá et al., 2007), decreased values of TBARS in cooked meat (Stamilla et al., 2020) or increasing the proportion of polyunsaturated fatty acids in the meat (Galli et al., 2020).

Many studies on oligosaccharides inclusion in animal diets, showed an increasing effect on mineral absorbtion and deposition (Scholz-Ahrens et al., 2007; Taranu et al., 2012; Untea \& Panaite., 2016) and other studies proved that organic acids had "nutritional effect" by increasing the minerals digestibility (Vieira et al., 2018). Considering the fact that zinc is a trace element with indirect antioxidant potential and previous research (Untea \& Panaite, 2016) showed a positive effect of chosen supplements on zinc deposition in meat and liver tissues, the study on the effect of dietary inclusion of synbiotics and organic acids on oxidative stability of meat can be considered as the main goal of the study.

\section{MATERIALS AND METHODS}

Ethical Commission of National Research and Development Institute for Biology and Animal Nutrition approved all experimental procedures and Directive 2010/63/EU was considered for protection of animals. 


\section{Experimental design}

The experiment consists on 120, 2 days old Ross 308 chicks, housed in metabolic cages (6 chicks/cage). A 2 × 2 factorial arrangement was considered with 4 treatments and 5 replicates ( 30 animals per group). Two different levels of synbiotic ( 0 and $10 \mathrm{~g} / \mathrm{kg}$ ) and two different levels of organic acids $(0$ and $1.5 \mathrm{~g} / \mathrm{kg}$ ) were added to the standard diets individual and in combinations in order to constitute the four experimental diets. The compound feeds formulations (Untea \& Panaite, 2016) are presented in tables 1-3. The inclusion levels are recommended by producer.

The synbiotic supplement was a commercial product, BiominR IMBO Pro/prebiotic, produced by BIOMIN, GmbH Austria, the organic acids used were BiotronicR SE Forte, produced by BIOMIN, GmbH Austria and organic zinc was chelated Zn, E.C.O.Trace ${ }^{\circledR}$ Trace minerals, produced by Biochem Zusatzstoffe Handels- und Produktionsgesellschaft mbH Küstermeyerstr, Germany.

\section{Chemical analysis}

Oxidative stability parameters were determined by using the methods of by Untea et al., (2019) as follows:

Total lipids were extracted using a chloroform/methanol mixture $(2: 1$, $\mathrm{v} / \mathrm{v}$ ). by Ferric thiocyanate method was used for peroxide value (PV) determination. The molecular absorptivity (560nm) for the solution formed by the lipid extract with chloroform/methanol, xylenol orange and $\mathrm{FeCl} 2$, was measured with a spectrophotometer (V-530 Jasco, Japan Servo Co. Ltd., Japan). Conjugated dienes (CD) and conjugated trienes (CT) was spectrophotometric measured at $233 \mathrm{~nm}$ and $268 \mathrm{~nm}$ from the dissolved lipid extract in isooctane. P-anisidine value was determined by measuring the absorptivity of the products formed from reaction of aldehydes with $\mathrm{p}$ anisidine reagent. The TBARS values (thiobarbituric acid reactive substances) were measured using third derivative spectrophotometry at $540 \mathrm{~nm}(\mathrm{sp} 3)$.

\section{Statistics}

The analytical results were analyzed using the XLSTAT software (Addinsoft, Paris, France). The data were analyzed by one-way analysis of variance (ANOVA) and Tukey test in order to highlight the statistical differences $(\mathrm{P}<0.05)$ between the groups. 
Table 1. Compound feeds formulation (phase I - starter)

\begin{tabular}{lcccc}
\hline \multicolumn{1}{c}{ Specification } & C (\%) & Syn (\%) & OA (\%) & Syn/0A (\%) \\
\hline Corn & 53.20 & 52.20 & 53.05 & 52.05 \\
Soybean meal & 38.70 & 38.70 & 38.70 & 38.70 \\
Oil & 3.06 & 3.06 & 3.06 & 3.06 \\
Monocalcium phosphate & 1.90 & 1.90 & 1.90 & 1.90 \\
Calcium carbonate & 0.92 & 0.92 & 0.92 & 0.92 \\
Salt & 0.37 & 0.37 & 0.37 & 0.37 \\
Methionine & 0.37 & 0.37 & 0.37 & 0.37 \\
Lysine & 0.25 & 0.25 & 0.25 & 0.25 \\
Choline & 0.06 & 0.06 & 0.06 & 0.06 \\
Threonine & 0.12 & 0.12 & 0.12 & 0.12 \\
Coccidiostats & 0.05 & 0.05 & 0.05 & 0.05 \\
Premix* & 1 & 1 & 1 & 1 \\
Synbiotic & - & 1 & - & 1 \\
Organic acids & - & - & 0.15 & 0.15 \\
\hline
\end{tabular}

*1 kg premix contains: $=1100000 \mathrm{IU} / \mathrm{kg}$ vit. A; $200000 \mathrm{IU} / \mathrm{kg}$ vit. D3; $2700 \mathrm{IU} / \mathrm{kg}$ vit. E; 300 $\mathrm{mg} / \mathrm{kg}$ Vit. K; $200 \mathrm{mg} / \mathrm{kg}$ Vit. B1; $400 \mathrm{mg} / \mathrm{kg}$ Vit. B2; $1485 \mathrm{mg} / \mathrm{kg}$ pantothenic acid; 2700 $\mathrm{mg} / \mathrm{kg}$ nicotinic acid; $300 \mathrm{mg} / \mathrm{kg}$ Vit. B6; $4 \mathrm{mg} / \mathrm{kg}$ Vit. B7; $100 \mathrm{mg} / \mathrm{kg}$ Vit. B9; $1.8 \mathrm{mg} / \mathrm{kg}$ Vit. B12; $2000 \mathrm{mg} / \mathrm{kg}$ Vit. C; $8000 \mathrm{mg} / \mathrm{kg}$ manganese; $8000 \mathrm{mg} / \mathrm{kg}$ iron; $500 \mathrm{mg} / \mathrm{kg}$ copper; $6000 \mathrm{mg} / \mathrm{kg}$ zinc; $37 \mathrm{mg} / \mathrm{kg}$ cobalt; $152 \mathrm{mg} / \mathrm{kg}$ iodine; $18 \mathrm{mg} / \mathrm{kg}$ selenium; $6000 \mathrm{mg} / \mathrm{kg}$ antioxidant.

Table 2. Diets formulation (grower stage)

\begin{tabular}{llccc}
\hline \multicolumn{1}{c}{ Specification } & C (\%) & Syn (\%) & OA (\%) & Syn/0A (\%) \\
\hline Corn & 54.78 & 53.78 & 54.63 & 53.63 \\
Soybean meal & 36.79 & 36.79 & 36.79 & 36.79 \\
Oil & 4.34 & 4.34 & 4.34 & 4.34 \\
Monocalcium phosphate & 1.65 & 1.65 & 1.65 & 1.65 \\
Calcium carbonate & 0.60 & 0.60 & 0.60 & 0.60 \\
Salt & 0.29 & 0.29 & 0.29 & 0.29 \\
Methionine & 0.29 & 0.29 & 0.29 & 0.29 \\
Lysine & 0.11 & 0.11 & 0.11 & 0.11 \\
Choline & 0.06 & 0.06 & 0.06 & 0.06 \\
Threonine & 0.04 & 0.04 & 0.04 & 0.04 \\
Premix* & 1 & 1 & 1 & 1 \\
Synbiotic & - & 1 & - & 1 \\
Organic acids & - & - & 0.15 & 0.15 \\
\hline
\end{tabular}

*1 kg premix contains: $=1100000 \mathrm{IU} / \mathrm{kg}$ vit. A; $200000 \mathrm{IU} / \mathrm{kg}$ vit. D3; $2700 \mathrm{IU} / \mathrm{kg}$ vit. E; 300 $\mathrm{mg} / \mathrm{kg}$ Vit. K; $200 \mathrm{mg} / \mathrm{kg}$ Vit. B1; $400 \mathrm{mg} / \mathrm{kg}$ Vit. B2; $1485 \mathrm{mg} / \mathrm{kg}$ pantothenic acid; 2700 $\mathrm{mg} / \mathrm{kg}$ nicotinic acid; $300 \mathrm{mg} / \mathrm{kg}$ Vit. B6; $4 \mathrm{mg} / \mathrm{kg}$ Vit. B7; $100 \mathrm{mg} / \mathrm{kg}$ Vit. B9; $1.8 \mathrm{mg} / \mathrm{kg}$ Vit. B12; $2000 \mathrm{mg} / \mathrm{kg}$ Vit. C; $8000 \mathrm{mg} / \mathrm{kg}$ manganese; $8000 \mathrm{mg} / \mathrm{kg}$ iron; $500 \mathrm{mg} / \mathrm{kg}$ copper; $6000 \mathrm{mg} / \mathrm{kg}$ zinc; $37 \mathrm{mg} / \mathrm{kg}$ cobalt; $152 \mathrm{mg} / \mathrm{kg}$ iodine; $18 \mathrm{mg} / \mathrm{kg}$ selenium; $6000 \mathrm{mg} / \mathrm{kg}$ antioxidant. 
Table 3. Diets formulation (finisher stage)

\begin{tabular}{lcccc}
\hline \multicolumn{1}{c}{ Specification } & C (\%) & Syn (\%) & OA (\%) & Syn/OA (\%) \\
\hline Corn & 60.31 & 59.31 & 60.16 & 59.16 \\
Soybean meal & 30.61 & 30.61 & 30.61 & 30.61 \\
Oil & 5.01 & 5.01 & 5.01 & 5.01 \\
Monocalcium phosphate & 1.61 & 1.61 & 1.61 & 1.61 \\
Calcium carbonate & 0.72 & 0.72 & 0.72 & 0.72 \\
Salt & 0.38 & 0.38 & 0.38 & 0.38 \\
Methionine & 0.22 & 0.22 & 0.22 & 0.22 \\
Lysine & 0.09 & 0.09 & 0.09 & 0.09 \\
Choline & 0.05 & 0.05 & 0.05 & 0.05 \\
Premix* & 1 & 1 & 1 & 1 \\
Synbiotic & - & 1 & - & 1 \\
Organic acids & - & - & 0.15 & 0.15
\end{tabular}

\begin{abstract}
*1 kg premix contains: $=1100000 \mathrm{IU} / \mathrm{kg}$ vit. A; $200000 \mathrm{IU} / \mathrm{kg}$ vit. D3; $2700 \mathrm{IU} / \mathrm{kg}$ vit. E; 300 $\mathrm{mg} / \mathrm{kg}$ Vit. K; $200 \mathrm{mg} / \mathrm{kg}$ Vit. B1; $400 \mathrm{mg} / \mathrm{kg}$ Vit. B2; $1485 \mathrm{mg} / \mathrm{kg}$ pantothenic acid; 2700 $\mathrm{mg} / \mathrm{kg}$ nicotinic acid; $300 \mathrm{mg} / \mathrm{kg}$ Vit. B6; $4 \mathrm{mg} / \mathrm{kg}$ Vit. B7; $100 \mathrm{mg} / \mathrm{kg}$ Vit. B9; $1.8 \mathrm{mg} / \mathrm{kg}$ Vit. B12; $2000 \mathrm{mg} / \mathrm{kg}$ Vit. C; $8000 \mathrm{mg} / \mathrm{kg}$ manganese; $8000 \mathrm{mg} / \mathrm{kg}$ iron; $500 \mathrm{mg} / \mathrm{kg}$ copper; $6000 \mathrm{mg} / \mathrm{kg}$ zinc; $37 \mathrm{mg} / \mathrm{kg}$ cobalt; $152 \mathrm{mg} / \mathrm{kg}$ iodine; $18 \mathrm{mg} / \mathrm{kg}$ selenium; $6000 \mathrm{mg} / \mathrm{kg}$ antioxidant.
\end{abstract}

\title{
RESULTS AND DISCUSSION
}

Regarding the production parameters registered in during experimental time, Untea et al., (2016) noticed that the mixture of suplements used, positively influenced the average body weight at 42 days and average daily weight gain compared to other groups.

Table 4. The influence of synbiotics $(\mathrm{g} / \mathrm{kg})$ and organic acids $(\mathrm{g} / \mathrm{kg})$ on lipid peroxidation parameters of broiler breast samples (day 0 )

\begin{tabular}{|c|c|c|c|c|c|c|c|c|}
\hline $\begin{array}{c}\text { Syn } \\
\text { OA }\end{array}$ & $\begin{array}{l}\mathbf{0} \\
\mathbf{0}\end{array}$ & $\begin{array}{c}10 \\
0\end{array}$ & $\begin{array}{c}0 \\
1.5\end{array}$ & $\begin{array}{l}10 \\
1.5\end{array}$ & SEM & $\begin{array}{c}\text { P val } \\
\text { Syn }\end{array}$ & $\begin{array}{c}\text { P val } \\
\text { OA }\end{array}$ & $\begin{array}{c}\text { P val } \\
\text { Syn } x \\
\text { OA }\end{array}$ \\
\hline \multicolumn{9}{|c|}{ Primary oxidation products } \\
\hline $\begin{array}{l}\mathrm{PV} \\
\left(\mathrm{Meq} \mathrm{O}_{2} / \mathrm{kg}\right)\end{array}$ & 0.132 & 0.148 & 0.127 & 0.135 & 0.0181 & 0.6535 & 0.7593 & 0.8974 \\
\hline $\begin{array}{l}\mathrm{CD} \\
(\mu \mathrm{mols} / \mathrm{g})\end{array}$ & 1.795 & 1.358 & 1.659 & 1.559 & 0.142 & 0.1959 & 0.8746 & 0.4139 \\
\hline $\begin{array}{l}\text { CT } \\
(\mu \mathrm{mols} / \mathrm{g})\end{array}$ & 3.068 & 2.731 & 2.960 & 3.565 & 0.251 & 0.6924 & 0.2895 & 0.1737 \\
\hline \multicolumn{9}{|c|}{ Secondary oxidation products } \\
\hline p-Anis & 60.81 & 58.10 & 40.49 & 52.619 & 5.380 & 0.4504 & 0.1072 & 0.3270 \\
\hline $\begin{array}{l}\text { TBARS } \\
(\mathrm{mg} / \mathrm{kg})\end{array}$ & $0.027 \mathrm{a}$ & $0.023^{\mathrm{ab}}$ & $0.020^{\mathrm{b}}$ & $0.021^{b}$ & 0.0008 & 0.0958 & 0.0008 & 0.0697 \\
\hline
\end{tabular}


The effects of selected supplements on oxidative stability of meat (breast samples) collected at the end of experiment and stored 0,4 and 7 days at $4^{\circ} \mathrm{C}$, are presented in tables 1,2 and 3.

At the end of experiment (day 0), an effect of supplements administrated was observed only for organic acid. The groups which received organic acids supplements registered significant decreasing values compared to control group. Decreased values were registered for both primary and secondary oxidation products, when the supplements were used individual (CT) or in mixture ( $\mathrm{CD}$ and $\mathrm{p}$ anis), but the differences were not statistically sustained. The same tendency was mainatained for TBARS, but the values recorded for OA supplemented groups were significantly decreased compared to control group.

In a study on broiler chicken (Dev et al., 2020) the results showed significant improvement of oxidative status of meat (breast and thigh) on determinations (TBARS; PV) performed on fresh samples ( 0 days of storage). In another study, the effect of a blend of organic acids was significant, only in combination with a mix of phytoadditives (Fascina et al., 2017).

Table 5. The influence of synbiotics $(\mathrm{g} / \mathrm{kg})$ and organic acids $(\mathrm{g} / \mathrm{kg})$ on lipid peroxidation parameters broiler breast samples (day 4)

\begin{tabular}{|l|c|c|c|c|c|c|c|c|}
\hline \multicolumn{1}{|c|}{$\begin{array}{c}\text { Syn } \\
\text { OA }\end{array}$} & $\mathbf{0}$ & $\mathbf{1 0}$ & $\mathbf{0}$ & $\mathbf{1 0}$ & SEM & $\begin{array}{c}\text { P val } \\
\text { Syn }\end{array}$ & $\begin{array}{c}\text { P val } \\
\text { OA }\end{array}$ & $\begin{array}{c}\text { P val } \\
\text { Syn } \mathbf{x} \\
\text { OA }\end{array}$ \\
\hline \multicolumn{7}{|c|}{ Primary oxidation products } \\
\hline $\begin{array}{l}\text { PV } \\
\left(\text { Meq } 0_{2} / \mathrm{kg}\right)\end{array}$ & 0.153 & 0.151 & 0.139 & 0.194 & 0.0131 & 0.1746 & 0.4033 & 0.1185 \\
\hline $\begin{array}{l}\mathrm{CD} \\
(\mu \mathrm{mols} / \mathrm{g})\end{array}$ & 9.546 & 8.845 & 9.917 & 9.349 & 0.9304 & 0.7221 & 0.6971 & 0.9044 \\
\hline $\begin{array}{l}\mathrm{CT} \\
(\mu \mathrm{mols} / \mathrm{g})\end{array}$ & 4.185 & 4.363 & 5.131 & 4.080 & 0.5196 & 0.5896 & 0.6610 & 0.4188 \\
\hline \multicolumn{7}{|c|}{ Secondary oxidation products } \\
\hline p-Anis & 79.03 & 62.78 & 70.168 & 63.667 & 6.301 & 0.2415 & 0.7373 & 0.6304 \\
\hline $\begin{array}{l}\text { TBARS } \\
(\mathrm{mg} / \mathrm{kg})\end{array}$ & $0.030^{\mathrm{a}}$ & $0.026^{\mathrm{ab}}$ & $0.025^{\mathrm{ab}}$ & $0.023^{\mathrm{b}}$ & 0.0010 & 0.0624 & 0.0218 & 0.5745 \\
\hline
\end{tabular}

After 4 days of storage at $4^{\circ} \mathrm{C}$, significant differences between groups were noticed for TBARS values. All experimental groups registered values below control group, but only the synergy of supplements conducted at a statistical significant result.

In the $3^{\text {rd }}$ table, are presented the results obtained for the studied parameters, after 7 days of storage at $4^{\circ} \mathrm{C}$. On the $7^{\text {th }}$ day of storage, the primary oxidation products showed significant decresed values under synbiotic supplements influence. The secondary oxidation products were significant improved for all experimental groups, in terms of TBARS values. 
In a study on lipid oxidation parameters (TBARS values) of broilers meat stored up to 30 days at $4^{\circ} \mathrm{C}$, the authors concluded that synbiotic supplementation had no significant effect on lipid peroxidation at any storage time at $1.5 \mathrm{~g} / \mathrm{kg}$ inclusion rate. A clear mechanism for antioxidant effect of synbiotics is not available at present.

Table 6. The influence of synbiotics $(\mathrm{g} / \mathrm{kg})$ and organic acids $(\mathrm{g} / \mathrm{kg})$ on lipid peroxidation parameters broiler breast samples (day 7)

\begin{tabular}{|c|c|c|c|c|c|c|c|c|}
\hline $\begin{array}{c}\text { Syn } \\
\text { OA }\end{array}$ & $\begin{array}{l}\mathbf{0} \\
\mathbf{0}\end{array}$ & $\begin{array}{c}10 \\
0\end{array}$ & $\begin{array}{c}0 \\
1.5\end{array}$ & $\begin{array}{l}10 \\
1.5\end{array}$ & SEM & $\begin{array}{c}\text { P val } \\
\text { Syn }\end{array}$ & $\begin{array}{c}\text { P val } \\
\text { OA }\end{array}$ & $\begin{array}{c}\text { P val } \\
\text { Syn } x \\
\text { OA }\end{array}$ \\
\hline \multicolumn{9}{|c|}{ Primary oxidation products } \\
\hline $\begin{array}{l}\mathrm{PV} \\
(\mathrm{Meq} \mathrm{O} / \mathrm{kg})\end{array}$ & $0.316^{\mathrm{a}}$ & $0.213^{\mathrm{b}}$ & $0.300^{\mathrm{a}}$ & $0.239^{a}$ & 0.0231 & 0.0435 & 0.8626 & 0.5479 \\
\hline $\begin{array}{l}\text { CD } \\
(\mu \mathrm{mols} / \mathrm{g})\end{array}$ & $12.425^{\mathrm{ab}}$ & $\begin{array}{c}10.613 \\
\mathrm{~b}\end{array}$ & $14.381^{\mathrm{a}}$ & $13.438^{\mathrm{ab}}$ & 0.5544 & 0.0753 & 0.0066 & 0.5900 \\
\hline $\begin{array}{l}\text { CT } \\
(\mu \mathrm{mols} / \mathrm{g})\end{array}$ & $6.128^{a}$ & $4.767 \mathrm{~b}$ & $6.202^{\mathrm{a}}$ & $5.235^{\mathrm{a}}$ & 5.6956 & 0.0351 & 0.0179 & 0.0452 \\
\hline \multicolumn{9}{|c|}{ Secondary oxidation products } \\
\hline p-Anis & 104.85 & 83.74 & 90.53 & 82.316 & 104.85 & 0.1155 & 0.4752 & 0.5305 \\
\hline $\begin{array}{l}\text { TBARS } \\
(\mathrm{mg} / \mathrm{kg})\end{array}$ & $0.037 \mathrm{a}$ & $0.032^{\mathrm{b}}$ & $0.030^{\mathrm{b}}$ & $0.031^{\mathrm{b}}$ & $0.037^{a}$ & 0.0469 & 0.0024 & 0.0327 \\
\hline
\end{tabular}

Some researchers found that inulin and modified forms of inulin presents radical scavenging activity, proving "in vitro" inhibitory effect on hydroxil radical and superoxide radical (Ren et al., 2011). Stamilla et al., (2020) showed that a significant effect of organic acids and plant extracts can be observed on cooked meat after 4 days of refrigeration, because cooked meat is more prone to peroxidation than raw meat. Previous studies demonstrated the link between prebiotic and organic acids presence in the broilers diets and improved mineral absorbtion and deposition (Untea \& Panaite., 2016; Vieira et al., 2018). Some authors reported results regarding the antioxidant potential of zinc and its effect in delaying of lipid peroxidation (Sahin and Kucuk, 2003; Zago and Oteiza 2001). The results of this experiment showed the enrichment of meat and liver in some minerals, (Untea \& Panaite., 2016) and this might be a possible explanation for the retarded effect of selected supplements on lipid peroxidation parameters.

In figure 1 are presented data regarding the trend of oxidation products evolution between groups, calculated as percentage difference between 0 and 7 days of storage.

The lipid peroxidation includes three steps. In the first one, an atom of hydrogen is abstracted from the lipid chain and a molecular rearrangement appears to form conjugated dienes and triens. It follows a propagation step, where the radical resulted in the previous step forms a lipid hydroperoxide 
and in the final step, the hydroperoxides are decomposed in secondary products like aldehydes and other products (Min and Ahn, 2005).

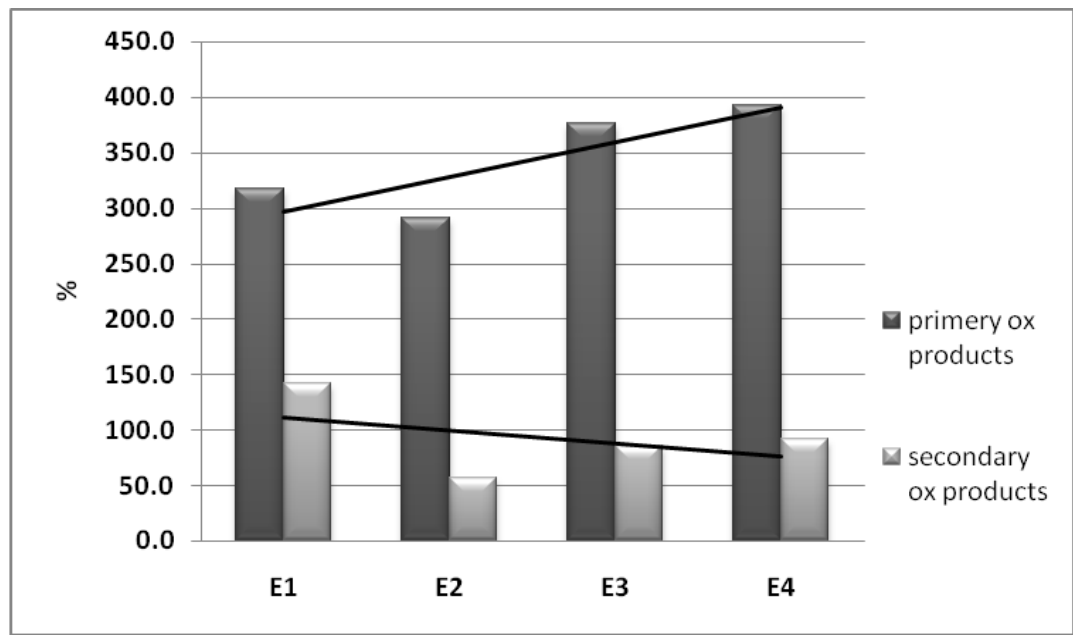

Figure 1. Percentage increase of lipid peroxidation products in 7 days storage time

The results from the graph, presented an antioxidant action mechanism of supplements on primary and secondary oxidation products. The primary oxidation products increased over 10 times in some situations (ex. conjugated diened) proving a rapid development of oxidation reactions. For groups which received $\mathrm{OA}$ supplements, the formation rate of primary products exceeded the control group, but in the same time, the formation of final oxidation products was delayed. This type of mechanism is related to "chain breaking" antioxidants which action by stalling the propagation phase of lipid peroxidation. This antioxidants are not effective on the first phase of peroxidation, but can inhibit the formation of final products of oxidation chain.

\section{CONCLUSION}

The results of the study showed an effective protection of lipid molecules of broilers meat induced by the supplementation of diets with a mix of synbiotics and organic acids. The improved oxidative stability of breast meat is an important marker of nutritional quality of animal products.

\section{ACKNOWLEDGEMENTS}

This research was funded by Romanian Ministry of Research and Innovation through Program 1 - Development National ResearchDevelopment, Sub-program 1.2 - Institutional Performance - Projects funding 
excellence in R \& D, Contract no. 17 PFE/ 17.10.2018, and project number 8 PCCDI 043 PC3.

\section{REFERENCES}

Abd El-Samee, L. D., El-Wardany, I., Abdel-Fattah, S. A., Abd El-Azeem, N. A., \& Elsharkawy, M. S., 2019. Dietary omega-3 and antioxidants improve long-chain omega-3 and lipid oxidation of broiler meat. Bulletin of the National Research Centre. 43(1), 45.

Dev, K., Mir, N. A., Biswas, A., Kannoujia, J., Begum, J., Kant, R., \& Mandal, A., 2020. Dietary synbiotic supplementation improves the growth performance, body antioxidant pool, serum biochemistry, meat quality, and lipid oxidative stability in broiler chickens. Animal Nutrition. 6, 325-332.

Fascina, V. B., Pasquali, G. A. M., Carvalho, F. B., Muro, E. M., Vercese, F., Aoyagi, M. M., \& Sartori, J. R., 2017. Effects of phytogenic additives and organic acids, alone or in combination, on the performance, intestinal quality and immune responses of broiler chickens. Brazilian Journal of Poultry Science. 19(3), 497-508.

Galli, G. M., Aniecevski, E., Petrolli, T. G., da Rosa, G., Boiago, M. M., Simões, C. A., Marcon, H. (2020). Growth performance and meat quality of broilers fed with microencapsulated organic acids. Animal Feed Science and Technology, 114706.

Garciá, V., Catalá-Gregori, P., HernáNdez, F., Megiás, M.D., Madrid, J., 2007. Effect of formic acid and plant extracts on growth, nutrient digestibility, intestine mucosa morphology, and meat yield of broilers. J Appl Poultry Res. 16:555-562.

Ghasemi, H. A., Shivazad, M., Mirzapour Rezaei, S. S., \& Karimi Torshizi, M. A., 2016. Effect of synbiotic supplementation and dietary fat sources on broiler performance, serum lipids, muscle fatty acid profile and meat quality. British poultry science. 57(1), 71-83.

Ghasemi, H. A., Shivazad, M., Mirzapour Rezaei, S. S., \& Karimi Torshizi, M. A., 2016. Effect of synbiotic supplementation and dietary fat sources on broiler performance, serum lipids, muscle fatty acid profile and meat quality. British poultry science. 57(1), 71-83.

Hassanpour, H., Moghaddam, A.Z., Khosravi, M., Mayahi, M., 2013. Effects of synbiotic on theintestinal morphology and humoral immune response in broiler chickens. Livest Sci. 153 (13), 116e22.

Khan, S. H., \& Iqbal, J., 2016. Recent advances in the role of organic acids in poultry nutrition. Journal of applied animal research. 44(1), 359-369. 
Liong, M.T., Dunshea, F.R., \& Shah, N.P., 2007. Effects of a synbiotic containing Lactobacillus acidophilus ATCC 4962 on plasma lipid profiles and morphology of erythrocytes in hypercholesterolaemic pigs on highand low-fat diets. British Journal of Nutrition. 98(4), 736-744.

Min, B. and Ahn, D.U. 2005. Mechanism of lipid peroxidation in meat and meat products - A review. Food Science and Biotechnology 14, 152-163.

Ren, J., Liu, J., Dong, F. \& Guo, Z., 2011. Highly efficient synthesis and antioxidant activity of O-(aminoethyl) inulin. Carbohydrate Polymers. 83: $1240-1244$.

Rodríguez-Lecompte, J.C., Yitbarek, A., Brady, J., Sharif, S., Cavanagh, M.D., Crow, G., Guenter, W., House, J.D., Camelo-Jaimes, G., 2012. The effect of microbial-nutrient interaction on the immune system of young chicks after early probiotic and organic acid administration. J Animal Sci. 90:2246-2254.

Sahin K and Kucuk O 2003. Zinc supplementation alleviates heat stress in laying Japanese quail. The Journal of Nutrition 133, 2808-2811.

Salah, A.S., El-Tarabany, M.S., \& Ali, M.A., 2019. Impact of dietary supplementation with a synbiotic, organic acids or their combination on growth performance, carcass traits, economic efficiency, jejunum histomorphometry and some blood indices of broiler chickens. Animal Production Science. 59(7), 1318-1326.

Shahidi, S., Maziar, Y., Delaram, N.Z., 2014. Influence of dietary organic acids supplementation on reproductive performance of freshwater Angelfish (Pterophyllum scalare). Global Vet. 13,373-377.

Scholz-Ahrens, K.E., Ade, P., Marten, B., Weber, P., Timm, W., Açil, Y. \& Schrezenmeir, J. 2007. Prebiotics, probiotics, and synbiotics affect mineral absorption, bone mineral content, and bone structure. The Journal of nutrition, 137 (3 Suppl 2), 838S.

Stamilla, A., Russo, N., Messina, A., Spadaro, C., Natalello, A., Caggia, C., \& Lanza, M., 2020. Effects of Microencapsulated Blend of Organic Acids and Essential Oils as a Feed Additive on Quality of Chicken Breast Meat. Animals. 10(4), 640.

Taranu, I., Marin, D.E., Untea, A., Janczyk, P., Motiu, M., Criste, R. D., \& Souffrant, W.B.,2012. Effect of dietary natural supplements on immune response and mineral bioavailability in piglets after weaning. Czech J Anim Sci, 57(7), 332-343.

Untea, A. E., \& Panaite, T. D., 2016. Effects of dietary symbiotics and organic acids on the mineral composition of broiler meat. Archiva Zootechnica. 19(2), 27.

Untea, A. E., Panaite, T. D., Dragomir, C., Ropota, M., Olteanu, M., \& Varzaru, I., 2019. Effect of dietary chromium supplementation on meat nutritional quality and antioxidant status from broilers fed with Camelina-mealsupplemented diets. Animal. 13(12), 2939-2947. 
Viana, F.M., Canto, A., Costa-Lima, B.R.C., Salim, A. \& Junior, C.C., 2017. Color stability and lipid oxidation of broiler breast meat from animals raised on organic versus non-organic production systems. Poultry science. 96(3), 747-753.

Vieira, B. S., Caramori, J. G., Oliveira, C. F. S., \& Correa, G. S. S. (2018). Combination of phytase and organic acid for broilers: role in mineral digestibility and phytic acid degradation. World's Poultry Science Journal, 74(4), 711-726.

Zago, M.P. and Oteiza, P.I., 2001. The antioxidant properties of zinc: interactions with iron and antioxidants. Free Radical Biology and Medicine 31, 266-274. 